\title{
Observations of the Use of Buildings by Free-ranging Elk, Cervus canadensis, in Prince Albert National Park, Saskatchewan
}

\author{
RYAN K. BROOK \\ Department of Animal and Poultry Science and the Indigenous Land Management Institute, College of Agriculture and \\ Bioresources, University of Saskatchewan, 51 Campus Drive, Saskatoon, Saskatchewan S7N 5A8 Canada; email: ryan \\ .brook@usask.ca
}

Brook, Ryan K. 2015. Observations of the use of buildings by free-ranging Elk, Cervus canadensis, in Prince Albert National Park, Saskatchewan. Canadian Field-Naturalist 129(3): 282-284

Elk (Cervus canadensis) are habituated to humans and associated buildings in many national parks in North America. During the summers of 2012-2014, observations were made of Elk standing on the decks of cabins and entering campground cook shelters in and around the town of Waskesiu in east-central Prince Albert National Park, Saskatchewan. These appear to be the first documented observations of Elk entering buildings intentionally. The reason for this behaviour is likely a combination of the animals seeking areas safe from wolves, thermal cover, and relief from biting insects.

Key Words: Elk behaviour; Cervus canadensis; Elk; habituation; buildings; Prince Albert National Park; Saskatchewan

Habituation occurs when wildlife decrease their response or cease to respond to a repeated stimulus that is normally not accompanied by positive or negative reinforcement (Thorpe 1956). This may include a significantly reduced fear of people and human-made environments (Thompson and Henderson 1998; Whittaker and Knight 1998). In national parks in North America, where wolves are present but hunting is forbidden, Elk (Cervus canadensis $)^{1}$ have often become habituated to humans and frequent areas near roads and buildings to avoid predation (Dekker and Slatter 2009). In many cases, this habituation has become pronounced, most notably in unhunted populations. For example, human visitors to Yellowstone National Park are injured by Elk every year by approaching habituated Elk too closely (Conover 2001). Although Elk use of areas close to roads and human dwellings has been well documented, I am not aware of any published reports of Elk entering buildings. This note includes such a report.

I observed and photographed free-ranging Elk in the town of Waskesiu and the adjacent campgrounds in east-central Prince Albert National Park, Saskatchewan $\left(53^{\circ} 56.1^{\prime} \mathrm{N}, 106^{\circ} 04.2^{\prime} \mathrm{W}\right)$. This area is dominated by mature spruce forest that last burned in 1919, mixed with patches of deciduous forest (Parks Canada 2011).

During the summers of 2012-2014, observations were made of Elk standing on the decks of cabins and entering campground cook shelters. Specifically, on 15 July 2012 at 1530, I observed an adult female Elk on a deck next to the front door of a cabin (Figure 1A). On 9 July 2013 at 1745, I saw another adult female Elk on the deck of a different cabin (Figure 1A). In both cases, the cabin owners were absent, but people were walking nearby and vehicles were driving along the roads directly adjacent to the cabins used by the Elk. Further,
I observed regular use of two campground cook shelters in the Beaver Glen campground near Waskesiu by a group of two adult male Elk (both with four-point antlers in velvet), one adult female, and two juveniles (Figure 1B-D) almost continuously during daylight hours on 12 and 13 July 2014. The animals remained inside the cook shelters for 8-49 minutes at a time, moving out to feed within $90 \mathrm{~m}$ of the shelter for 17 44 minutes, before returning to the shelter. Discussions with local cabin owners indicated that this behaviour is not uncommon during the summer in and around Waskesiu. All of these observations were made when the ambient temperature was above $20^{\circ} \mathrm{C}$ and the activity of biting flies, including mosquitoes (Culex sp.), black flies (Simulium sp.), and horseflies (Chrysops sp.), was high.

These observations of free-ranging Elk using human dwellings represent extreme examples of their habituation to humans. This behaviour is most likely a result of predator and insect avoidance as well as seeking thermal cover and forage access. Elk herds in Jasper National Park (Dekker et al. 1995) and Banff National Park (McKenzie 2001), Alberta, are both concentrated near the park town sites where large carnivores are less common. Although rarely studied in Elk, biting flies have been reported to have a considerable impact on ungulates, disrupting feeding and resting (Downes et al. 1986) and prompting animals to seek relief areas that are cooler and vegetation free and where biting flies are less abundant (Boertje 1981). Buildings provide significant thermal cover in the form of shade, lower ambient temperature, reduced absorption of solar radiation by animals, and direct conduction of body heat when the animal is lying on cement. Forage may also play a role, as gardens and other high-quality fertilized and watered

\footnotetext{
${ }^{1}$ The taxonomy of the Red Deer-Elk-Wapiti complex in the Cervidae family has yet to be fully resolved. I use Cervus canadensis here, following the IUCN Redlist (Lovari et al. 2008), based on the recommendations of Geist (1998) and recent genetic work by Randi et al. (2001) and Ludt et al. (2004).
} 


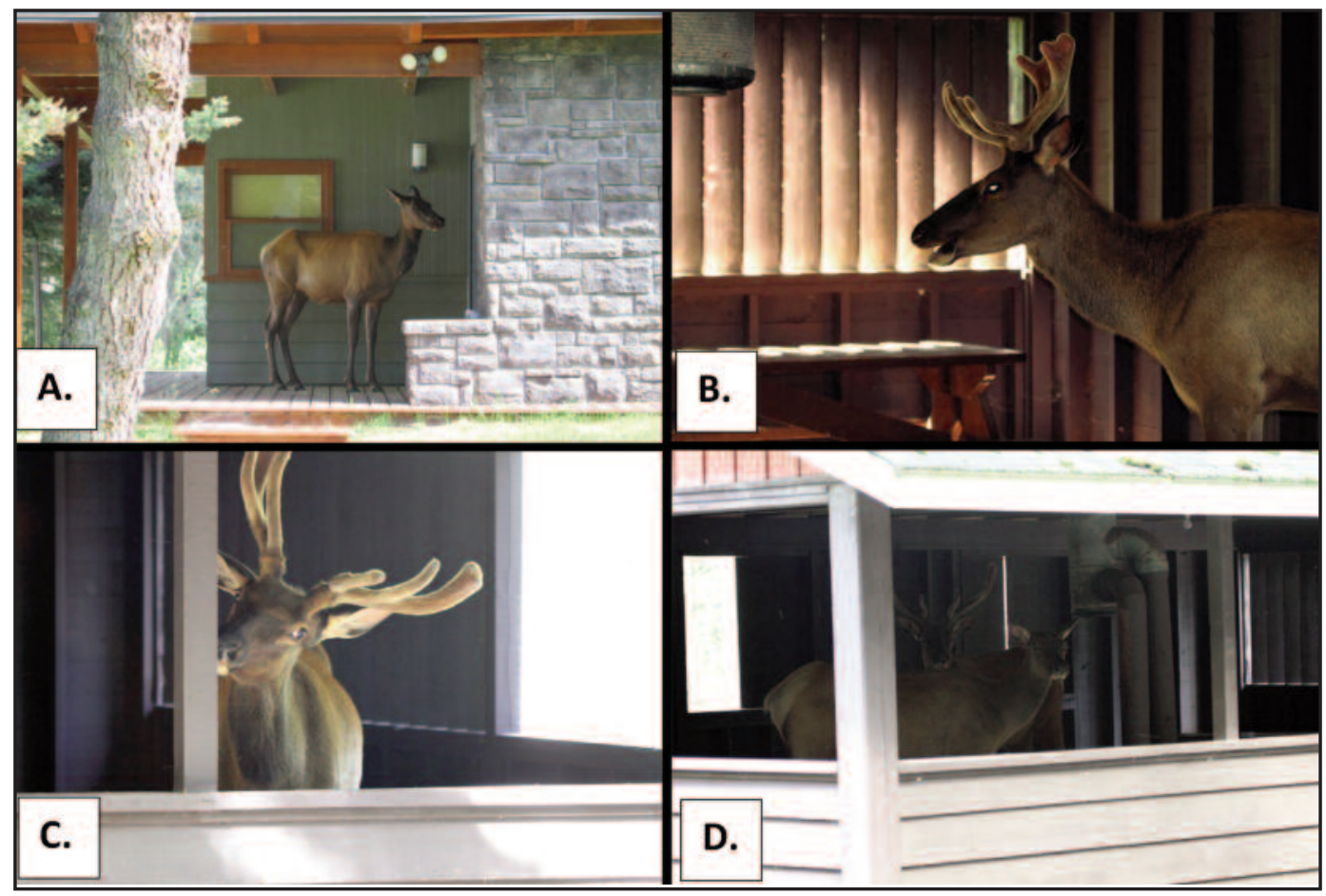

FIGURE 1. (A) Free-ranging adult female Elk (Cervus canadensis) on the porch of a cabin in Waskesiu, Prince Albert National Park, Saskatchewan (13 July 2012). (B) Male Elk in a cook shelter in the Beaver Glen campground near Waskesiu (12 July 2014). (C) Male Elk in another cook shelter (13 July 2014). (D) One female and one male Elk in a cook shelter (13 July 2014). Photos: Ryan K. Brook.

plants are available near the buildings. The use of buildings that are vegetation free may involve a trade-off between seeking forage and avoiding predation. McKenzie (2001) found that Elk in Banff made greater use of urbanized areas in both summer and winter and that urban Elk had a significantly higher rate of survival that Elk using wilderness areas.

The use of buildings by Elk is viewed positively by many park visitors who enjoy seeing and approaching Elk to photograph and observe them. I regularly observed people approaching within $5 \mathrm{~m}$ of the Elk that were using the dwellings. However, this Elk behaviour could become an increasing nuisance as these animals defecate and feed on flower gardens and lawns. Habituated Elk can also become a public health risk and are associated with significant liability issues. Further research and monitoring is required to characterize the frequency, timing, and extent of habituation in the local Waskesiu Elk herd. A wide range of management options is available to deal with habituated Elk; they must be non-lethal to be used in a national park and can include hazing to scare Elk and instill a greater fear response toward people and buildings. Other options include translocation of problem animals, application of chemical repellants, and fencing (Walter et al. 2010).

\section{Acknowledgements}

This study was funded by the University of Saskatchewan. The Wildlife Ecology and Community Engagement Lab provided ongoing input and support.

\section{Literature Cited}

Boertje, R. D. 1981. Nutritional ecology of the Denali caribou herd. M.Sc. thesis, University of Alaska, Fairbanks, Alaska, USA.

Conover, M. R. 2001. Resolving Human-Wildlife Conflicts: The Science of Wildlife Damage Management. CRC Press, Cleveland, Ohio, USA.

Dekker, D., W. Bradford, and J. R. Gunson. 1995. Elk and Wolves in Jasper National Park, Alberta - From historical times to 1992. Pages 85-94 in Ecology and Conservation of Wolves in a Changing World. Occasional publication 35. Edited by L. N. Carbyn, S. H. Fritts, and D. R. Seip. Canadian Circumpolar Institute, Edmonton, Alberta, Canada.

Dekker, D., and G. Slatter. 2009. Wolf, Canis lupus, avoidance behaviour of American Elk, Cervus elaphus, in Jasper National Park, Alberta. Canadian Field-Naturalist 123: 236-239.

Downes, C. M., J. B. Theberge, and S. M. Smith. 1986. The influence of insects on the distribution, microhabitat choice, and behaviour of the Burwash caribou herd. Canadian Journal of Zoology 64: 622-629. 
Geist, V. 1998. Deer of the World: Their Evolution, Behavior, and Ecology. Stackpole Books, Mechanicsburg, Pennsylvania, USA.

Lovari, S., J. Herrero., J. Conroy, T. Maran, G. Giannatos, M. Stubbe, S. Aulagnier, T. Jdeidi, M. Masseti, L. Nader, K. de Smet, and F. Cuzin. 2008. Cervus elaphus. The IUCN Red List of Threatened Species. Version 2015.2. Accessed 1 September 2015. www.iucnredlist.org.

Ludt, C. J., W. Schroeder, O. Rottmann, and R. Kuehn. 2004. Mitochondrial DNA phylogeography of red deer (Cervus elaphus). Molecular Phylogenetics and Evolution 31: 1064-1083.

McKenzie, J. A. 2001. The demographic and nutritional benefits of urban habitat use by elk. M.Sc. thesis, University of Guelph, Guelph, Ontario, Canada.

Parks Canada. 2011. Urban forest renewal in Waskesiu: Prince Albert National Park Backgrounder. Parks Canada, Ottawa, Ontario, Canada. Accessed 14 July 2014. http:// www.waskesiu.org/mrws/filedriver/Sept_2011_Urban_For est_Renewal_BKG.pdf.
Randi, E., N. Mucci, F. Claro-Hergueta, A. Bonnet and E. J. P. Douzery. 2001. A mitochondrial DNA control region phylogeny of the Cervinae: speciation in Cervus and implications for conservation. Animal Conservation 4: 1-11.

Thompson, M. J., and R. E. Henderson. 1998. Elk habituation as a credibility challenge for wildlife professionals. Wildlife Society Bulletin 26: 477-483.

Thorpe, W. H. 1956. Learning and Instinct in Animals. Methuen, New York, New York, USA.

Walter, W. D., M. J. Lavelle, J. W. Fischer, T. L. Johnson, S. E. Hyngstrom, and K. C. Vercauteren. 2010. Management of damage by elk (Cervus elaphus) in North America: a review. Wildlife Research 37: 630-646.

Whittaker, D., and R. L. Knight. 1998. Understanding wildlife responses to humans. Wildlife Society Bulletin 26: 312-317.

Received 19 July 2014

Accepted 6 June 2015 